\section{Recent Developments in Czech Higher Education}

\section{Ladislav Cerych}

Ladislav Cerych is director of the Educational Policy Center and a member of the education faculty at Charles University in the Czech Republic. Address: Myslikova 7, 11000 Prague 1, Czech Republic.

$\mathrm{T}$ he most important recent development in Czech higher education is without a doubt the parlimentary adoption in April 1998 of a new law governing higher education institutions. Replacing the May Law of 1990, the new law has several features that represent important innovations in the Czech context. It should be stated at the outset that the changes-and the law that introduces them-may in time be considered a milestone in the development of Czech higher education.

To begin, however, preliminary mention should be made of the main steps in Czech higher education development since the end of the communist regime in November 1989.

\section{Post-1989 Developments}

The first important event was the adoption of the abovementioned law in May 1990. Prior to 1990, the most repressive features of the communist system had already been abolished. These features included: political and ideological control of the system and of its institutions, compulsory teaching of Marxism-Leninism, extreme centralization, and the external appointment of most university rectors and deans. The key feature of the 1990 Law was the re-establishment of institutional autonomy, which, in fact, became very prominent. The Law contained several other innovations such as the creation of a new degree and the creation of an independent accreditation system. In general, it can probably be said that its effects were overall very positive overall.

\section{In the early 1990s, only about 15 per- cent of the eligible age-cohort advanced to higher education. By 1997-98 around 25 percent of the age group were de- ciding to participate in postsecondary education.}

From a comparative perspective, student enrollments in Czech higher education had been quite low.
In the early 1990s, for instance, only about 15 percent of the eligible age-cohort advanced to higher education. Student numbers have increased very rapidly over the past 6 to 8 years. In fact, new entrants nearly doubled, and by 1997-98 around 25 percent of the age group were deciding to participate in postsecondary education. At the same time, less that 50 percent of applicants seeking entry into higher education are being admitted.

Higher education was not a priority for the Czech government: public higher education expenditures remained virtually constant (which meant a substantial decline in real expenditures per student). At the same time, expenditures on secondary vocational education doubled in real terms.

\section{Until 1998, the Czech system of higher education consisted of $\mathbf{2 7}$ universities and other more specialized institutions of higher learning that offered de- grees after four to six years of study.}

Until 1998, the Czech system of higher education consisted of 27 universities and other more specialized institutions of higher learning that offered degrees after four to six years of study. The system did not include a nonuniversity sector-institutions with programs of shorter duration and with a more vocational orientation such as the American community colleges, the German Fachbochschulen, or the French $\mathcal{F} U T$ s. In other words, the system was little diversified. One exception was the creation in 1996 of postsecondary professional schools, having a vocational orientation and offering three-year educational programs. These schools were not recognized as part of the general higher education system, however, and their status was never clearly defined.

Finally, it is noteworthy that the Czech system of postsecondary education, unlike other Central and Eastern European countries, has not encouraged the creation and development of private higher education.

To some extent at least, the new law of April 1998 can be considered an attempt to compensate for the past and present shortcomings of the higher education system. The law may also address what has been criticized as a central feature of post-1990 developments-namely, that the changes did not represent a revolution but rather a restoration of the pre-1939, if not 19 th-century Humboldtian system. 
Benefits of the 1998 Law

In the main, the new law opens up and diversifies the Czech system. First, its preamble defines some new functions and roles of higher education never mentioned in the past. These include the role of universities in adult education and life-long learning, and cooperation on the regional and international level.

Second, the new law explicitly refers to nonuniversity institutions of higher education, which, as mentioned earlier, did previously exist in the Czech system. Traditional higher education institutions had generally been opposed to their creation, in part because they feared that the new institutions would subtract from the already meager public resources available to them. Today, it is generally assumed that some of the better and more established professional schools will, after appropriate accreditation, achieve a certain degree of status within the new nonuniversity education sector and thus become a recognized part of higher education. In any case, this clause of the law represents an important potential tool for diversifying Czech higher education, as it expands to help meet the growing and diverse needs of the economy.

Third, the new law encourages the creation and development of private higher education institutions. At this point it is not clear how many private institutions will actually emerge. In general, it is expected that they will not be numerous, at least not in the immediate future, since they will be subject to the same strict accreditation measures as public universities and because both qualified staff and financial resources are presently quite scarce. There will probably be more room for institutions of the nonuniversity type created by local industrial or financial groups.

Fourth, another innovation in the law is the addition of a new board within the internal structure of the university. Board members are expected to represent organizations or sectors external to the institution such as local authorities and public interests. Although the role of this board is mainly advisory - except in matters concerning acquisition and transfers of the university's real estate assets- this innovation reflects an important opening of higher education to broader influences and concerns. American university boards of trustees served, to a limited extent, as a model for the new Czech university boards, although the former are endowed with much greater powers that the latter.

Finally, the law addresses not only the rights and prerogatives of universities, but also their obligations. The most important such obligation is the institution's duty to publish an annual detailed report on its activities and also prepare and publish its long-term program and strategy. No less important is the duty of the Ministry of Education to formulate and present the country's long-term higher education policy. Both these points are quite essential in the Czech context because to many observers, a key weakness of the past and existing system has been the absence of a comprehensive long-term concept and policy at the institutional as well as system level.

An important point should be added here with regard to public higher education fees, which formerly did not exist. During the preparation of the law, this point was the subject of a heated political debate. In the end, those opposed to fees won and students at public institutions will pay no fees, although a small step in this direction was introduced: students will be required to pay fees if they prolong their studies beyond their prescribed duration. Extensions are possible on social or health grounds.

\section{It is noteworthy that the Czech system of postsecondary education, unlike other Central and Eastern European countries, has not encouraged the cre- ation and development of private higher education.}

\section{Shortcomings of the 1998 Law}

The new law has several shortcomings. Most of them are linked to the past or are related to the resistance of the Czech system (like many others) to change. Three shortcomings warrant brief mention here.

First, although the law implies a significant opening of Czech higher education, it still remains fairly closed. For instance, it does not provide any space for exceptions in matters of student admissions or procedures for faculty appointments that remain very complex and rigid.

Second, while in several instances the law is overly detailed and rigid (which in many ways reflects the legalistic traditions of the country and of Central Europe more generally), on some points it is extremely vague. For example, it contains virtually no provisions regarding the function, structure, and management of the new nonuniversity institutions, an otherwise important innovation in the Czech context. This means that their future development and shape are uncertain and almost entirely subject to the implementation process with all its tensions and existing resistance.

Third, and this is linked to the second point, whether or not the law eventually appears as a milestone in the development of Czech higher education (as suggested at the outset here) will to a large extent depend on how it is implemented. Implementation is of course always important, but in this case it could become a major problem and weakness of the new law. However, it is also a challenge to which, hopefully, the system and its actors will be able to respond. The new law is certainly an important potential tool in this sense. 